\title{
Man-made changes in flora and vegetation: a sketch to a scientific portrait of Professor Herbert Sukopp
}

\author{
Bogdan Jackowiak
}

Department of Systematic and Environmental Botany, Faculty of Biology, Adam Mickiewicz University in Poznań, Poland, e-mail: bogjack@ amu.edu.pl; ORCID: https://orcid.org/0000-0003-1684-7380

\begin{abstract}
The changes in plant cover have been the subject of regular geobotanical research for over 150 years. For several decades, one of the most outstanding researchers of this process has been Professor Herbert Sukopp from the Technische Universität Berlin. This paper discusses the main concepts and most important results of his empirical research. Based on the analysis of international scientific information database resources (Scopus, Web of Science, Google Scholar), the worldwide impact of Sukopp's publications on the development of research in the field of anthropogenic changes in flora and vegetation was illustrated.
\end{abstract}

Key words: flora, vegetation, anthropogenic changes, plant migration, hemeroby, extinction, knowledge dissemination

I dedicate this paper to Professor Herbert Sukopp to commemorate his 90th birthday anniversary.

\section{Introduction}

The influence of humans on the natural environment and its components increases with the progress of civilization (Roberts 2014). As indicated by Steffen et al. (2007): "The human imprint on the global environment has now become so large and active that it rivals some of the great forces of Nature in its impact on the functioning of the Earth system". The development of agriculture, industrialization and urbanization leads to, among others, changes in plant cover. In the words of Behre (1988): "Today's cultural landscape is the result of human impact upon natural ecosystems over millennia and, in more recent times, the purposeful creation of a landscape specifically for agricultural production. In densely inhabited regions, i.e., in large parts of Europe, human activity completely masks the natural factors. Thus, it is scarcely possible to recognize natural alterations during later periods using the presently available methods of vegetation history. This applies to central and northern Europe from the Middle Ages onwards and to the Mediterranean area since antiquity".

Anthropogenic changes in flora and vegetation have been the subject of regular geobotanical research for over 150 years (Candolle 1855). For several decades, one of the most outstanding researchers of this process has been Professor Herbert Sukopp from the Technical University in Berlin, who, in 2020, celebrates his 90th birthday. This year is also the 65th anniversary of his extremely fruitful creative work, started with a publication about halophytes (Sukopp 1955). These events inspire reflection on the role of Sukopp in the development of science, in particular, geobotany and ecology. At the beginning of this year, an excellent analysis of the achievements of Herbert Sukopp was published, showing his pioneering role in the development of the urban ecology (Kowarik 2020). This paper focuses on the Sukopp's ideas, concepts and empirical research in the field of anthropogenic changes in flora and vegetation. This publication and multiple personal contacts 
between the author of this article and Professor Sukopp confirm that this issue is the main motive of his research activity. This was already indicated by Olaczek (1998), who distinguished three main directions in Sukopp's scientific achievements: (1) changes in flora and vegetation under the influence of human activity; (2) flora extinction and protection; (3) urban ecology - as a new scientific discipline.

The aim of this study is to discuss the main trends of Sukopp's research on the relationship between humans and flora and vegetation, and to show their measurable impact on the development of knowledge about anthropogenic changes in flora and vegetation.

\section{Brief scientific biography of Professor Herbert Sukopp}

Prof. Herbert Sukopp was born in Berlin on November 6,1930 . In the same city, he also graduated in botany, geology and sociology. He obtained his doctorate in natural sciences in 1958 under the supervision of Professor Erich Werderman at the Freie Universität Berlin. Ten years later, Herbert Sukopp obtained his habilitation at the Technical University of Berlin. In 1969 he was appointed a professor; from 1974 to 1996, he was a full professor and the head of the Department of Ecosystem Research and Vegetation Sciences at the Institute of Ecology TU Berlin.

Detailed information on many functions and scientific activities of Professor Sukopp can be found in the book published in 1995, on the occasion of the 65th anniversary of his birthday, entitled "Dynamik und Konstanz. Festschrift für Herbert Sukopp" [English: Dynamism and constancy. Festschrift for Herbert Sukopp] (Kowarik et al. 1995). This book also includes a list of Sukopp's publications, which appeared in the years 1955-1994 (Maubach 1995). The list of later published works is available on the website of his parent department (Kowarik 2020).

Professor Sukopp enjoys great authority in many countries of the world. In his native country, he was repeatedly honored for scientific and nature protection activities, and awarded with medals. An expression of great appreciation and respect in Poland was granting Professor Sukopp the title of an honorary member of the Polish Botanical Society (PBS). On this occasion, he participated in the $51^{\text {st }}$ PBS Congress in Gdańsk in 1998 and gave a lecture entitled "Urban ecology scientific and practical aspects". In connection with this event, a special edition of the "Phytocoenosis" journal, dedicated to the Professor, was published. The volume entitled "Synanthropization of Plant Cover in New Polish Research" (Faliński et al. 1998) contains several dozen articles related to the research topics of Professor Sukopp that are described in this paper.

\section{Material and methods}

The analysis is based on Sukopp's publications on anthropogenic changes in flora and vegetation, excluding works focused on urban flora and vegetation, which were discussed by Kowarik (2020). Publications selected for this analysis were cited in journals indexed in global databases: Scopus or Web of Science. In the case of Scopus, both the citations of publications indexed in the Documents database and in the Second documents database were taken into account. In the case of Web of Science, there were considered both the citations of Web of Science Core Collections indexed publications and works whose citations are available using the Cited Reference Search tools. The inclusion of Second documents and the use of Cited Reference Search tools allow a fairly complete understanding of the scope of impact of the author's publications, whose output covers the years 1955-2020. The publications separated in this way were quantified in the Google Scholar database, which provides an image of their use not only on an international scale, but also on a regional and local scales. All quantitative data refer to the end of 2020 .

The result of the conducted analysis is an attempt to define the key issues undertaken by Sukopp in the field of anthropogenic changes in flora and vegetation (Chapters 4 and 5). Using the tools available in the Scopus, Web of Science and Google Scholar databases, quantitative data were presented, indicating the scope of dissemination of his scientific work (Chapter 6).

\section{Sukopp's core concepts of the relationship between humans and flora and vegetation}

\subsection{Beginning of research - halophytes, peat bogs, and neophytes}

From the beginning of his research activity, Herbert Sukopp noticed and took into account the importance of the human factor in shaping the plant cover. After his debut paper on halophytes and floristic notes, which were published in 1955-1957 (Sukopp 1955, 1957), in 1959 , he submitted a dissertation on peat bog vegetation. Comparing the vegetation of Berlin's peat bogs, he paid special attention to its "anthropogenic changes" (Sukopp 1959/60). Two years later (in 1961), during the International Symposium in Stolzenau dedicated to anthropogenic vegetation, he delivered a lecture on neophytes occurring in natural plant communities in Europe. This lecture, published only in 1966 (Sukopp 1966a), and the article on the same issue from 1962 (Sukopp 1962) open up a long list of his publications on neophytes in the flora of Europe and also define problems that need to be solved. 


\subsection{Human influence on flora and vegetation}

Looking from today's perspective, it is necessary to emphasize the special importance of two papers published at the turn of the 1960s and 1970s: "Human impact on vegetation" (Sukopp 1969) and "Man-made changes to flora and vegetation in Central Europe" (Sukopp 1972). In these papers, Herbert Sukopp synthesized the existing knowledge about relationship between humans and flora and vegetation, presented key terms for its description and proposed a method for measuring the impact of culture on ecosystems. In the first work, he focused on man and his influence on flora and vegetation, developing the following theses:

- the influence of man on the plant cover comprises not only the impact of an individual, but also all his economic activities, and even more broadly, cultural activities;

- such understood 'human influence' is a habitat factor, the effect of which is visible both in the structure and functioning of vegetation;

- this factor varies depending on the Earth's vegetation zone and the phase of socio-economic development, therefore, it is necessary to take into account the dimensions that enable their comparison, such as: intensity, time and spatial extent of the impact.

Based on these assumptions, Herbert Sukopp presented conclusions from a comparative analysis of the previously known classifications of human influence on ecosystems, indicating that the idea of hemeroby (Jalas 1953, 1955) may be particularly useful in geobotanical research. According to this idea, human influence on the ecosystem is measured using a multi-level scale of hemeroby. Herbert Sukopp proposed that this assessment should take into account: type, intensity and duration of cultural impact, condition of the habitat (substrate, soil, water, etc.), species composition and vegetation structure. The word 'hemerob' used in this concept comes from the Greek word 'hemeros', which means "tame, cultivated:", and the word 'bios', meaning 'life'. The hemeroby scale, referring to the Kolkwitz and Marsson saprobia system (Kolkwitz 1950) used in limnology, was supplemented and developed in the consecutive years by Sukopp (Table 1) (Sukopp 1972; Blume \& Sukopp 1976) and other authors, in particular, Kowarik (1988).

The concept of hemeroby has found wide application in Europe, not only in geobotanical and ecological research, but also in landscape studies (see Chapter 6).

\subsection{Changes in plant cover under human influence}

The first attempt to define anthropogenic changes in flora and vegetation was made by Sukopp in his article on species losses in the flora of Berlin (Sukopp 1966: 135). He wrote there as follows: "The influence of humans can be seen in the decline of species as well as in the naturalization of alien species. 'Poverty' and 'enrichment' are each only one aspect of these effects of human influence."(translation BJ). This definition was significantly deepened in the work published by Sukopp three years later (1972) and summarizing an important stage of his scientific activity. According to the concept presented there, anthropogenic changes in plant cover are manifested at many levels of its organization (population, species, floristic, phytocoenotic) and include two dynamically opposing phenomena: the decline of native plant species and indigenous communities and the spread of alien species and phytocoenoses dominated by them.

The following factors are important in the spread of alien species: time of immigration, the way in which humans participate in their immigration and the degree of naturalization. The spread of alien species is also determined by a geographical zone, the respective plant's habitat and its community. The expansion of species beyond their natural ranges may lead to the evolution of new taxa. Such a comprehensive approach to the problem of the relationship between humans and flora and vegetation was extremely innovative at that time. It was reflected in the structure of the work from 1972, which can be considered crucial in the history of research on anthropogenic changes of flora and vegetation, thus, it is worth quoting it in full (Table 2).

The concept of contemporary changes in flora and vegetation presented in the discussed publications has been developed with further theoretical assumptions and illustrated with examples in the work entitled "Extinction and Naturalization of Plant Species as Related to Ecosystem Structure and Function" (Sukopp \& Trepl 1987). This study again indicates that anthropogenic changes in plant cover are primarily due to two phenomena: (1) extinction and decline of species and (2) introduction and naturalization of species. This time, however, special emphasis was placed on the importance of the historical factor, stating in the conclusion (p. 270):

"Generalizing and actualistic studies are of value only in an essentially historical theoretical framework. This becomes particularly obvious if one considers two historical processes which truly revolutionized the structure and function of actual biotic communities, i.e., the breakdown of barriers between isolated plant and animal territories which had existed since the Tertiary Period, beginning with the development of worldwide transportation routes around the year 1500; and the rapidly accelerated extermination of species which began in the middle of the 20 th century." 
Table 1. Gradations of different forms of land use according to the degree of cultural influence on ecosystems (according to Blume \& Sukopp 1976; English translation - BJ)

\begin{tabular}{|c|c|c|c|c|c|}
\hline \multirow[b]{3}{*}{ Hemerobic level } & \multirow[b]{3}{*}{ Ecosystems } & \multirow[b]{3}{*}{ Anthropogenic impact } & \multicolumn{3}{|c|}{ Changes in vegetation and flora } \\
\hline & & & \multirow[t]{2}{*}{ Vegetation } & \multicolumn{2}{|c|}{ Flora of vascular plants* } \\
\hline & & & & $\begin{array}{l}\text { Share of } \\
\text { neophytes in } \\
\text { the species } \\
\text { composition }\end{array}$ & $\begin{array}{l}\text { Share of } \\
\text { therophytes } \\
\text { in the } \\
\text { species } \\
\text { composition }\end{array}$ \\
\hline 1 & 2 & 3 & 4 & 5 & 6 \\
\hline ahemerobic & $\begin{array}{l}\text { rocky, moor and tundra } \\
\text { regions in some parts of } \\
\text { Europe; in Central Europe } \\
\text { - only some areas of high } \\
\text { mountains }\end{array}$ & absent & $\begin{array}{l}\text { water, bog and rock } \\
\text { vegetation in some parts } \\
\text { of Europe; in Central } \\
\text { Europe - only fragments } \\
\text { of high mountain } \\
\text { vegetation }\end{array}$ & $0 \%$ & \multirow{3}{*}{$<20 \%$} \\
\hline oligohemerobic & $\begin{array}{l}\text { weakly thinned or weakly } \\
\text { grazed forests, salt marshes, } \\
\text { growing dunes, growing fens } \\
\text { and raised bogs }\end{array}$ & $\begin{array}{l}\text { small-scale wood removal, } \\
\text { grazing, air (e.g. } \mathrm{SO}_{2} \text { ) and } \\
\text { water immissions (e.g. } \\
\text { floodplain flooding with } \\
\text { eutrophic water) }\end{array}$ & $\begin{array}{l}\text { weakly thinned or } \\
\text { weakly grazed forests, } \\
\text { salt marshes, growing } \\
\text { dunes, growing fens } \\
\text { and raised bogs, } \\
\text { some aquatic plant } \\
\text { communities }\end{array}$ & $<5 \%$ & \\
\hline mezohemerobic & $\begin{array}{l}\text { forests composed of habitat } \\
\text { alien species, heaths, dry and } \\
\text { poor grasslands, landscape } \\
\text { parks (extensive meadows } \\
\text { and pastures) }\end{array}$ & $\begin{array}{l}\text { thinning and rarely plowing } \\
\text { or logging, mulch use and } \\
\text { pest control, sometimes } \\
\text { poor fertilization }\end{array}$ & $\begin{array}{l}\text { vegetation pattern } \\
\text { influenced by humans }\end{array}$ & $5-12 \%$ & \\
\hline \multirow[t]{2}{*}{ euhemerobic $\beta$} & $\begin{array}{l}\text { intensive grazing and } \\
\text { forestry; ornamental lawns }\end{array}$ & $\begin{array}{l}\text { fertilization, liming, use } \\
\text { of biocides, slight ditch } \\
\text { drainage }\end{array}$ & \multirow{2}{*}{$\begin{array}{l}\text { numerous, mostly } \\
\text { persistent ruderal } \\
\text { communities of arable } \\
\text { and garden weeds, } \\
\text { ornamental lawns; } \\
\text { forests composed of } \\
\text { non-native and habitat- } \\
\text { alien species }\end{array}$} & $13-17 \%$ & $21-30 \%$ \\
\hline & arable land & $\begin{array}{l}\text { leveling, constant } \\
\text { disturbance, massive } \\
\text { mineral fertilization }\end{array}$ & & \multirow{3}{*}{$18-22 \%$} & \multirow{3}{*}{$30-40 \%$} \\
\hline \multirow{2}{*}{ euhemerobic $\alpha$} & $\begin{array}{l}\text { special crops (e.g. fruits, } \\
\text { vines, ornamental lawns) or } \\
\text { crop rotations with strongly } \\
\text { selected weed flora }\end{array}$ & $\begin{array}{l}\text { deep plowing (or trenches), } \\
\text { permanent and deep } \\
\text { drainage (and/or intensive } \\
\text { irrigation); Intensive } \\
\text { fertilization (manure) and } \\
\text { the use of biocides }\end{array}$ & \multirow{4}{*}{$\begin{array}{l}\text { low-competition pioneer } \\
\text { biocenoses, e.g., many } \\
\text { short-lived ruderal } \\
\text { communities }\end{array}$} & & \\
\hline & sewage fields & $\begin{array}{l}\text { adaptive; heavy irrigation } \\
\text { with drainage }\end{array}$ & & & \\
\hline \multirow[t]{2}{*}{ polyhemerobic } & $\begin{array}{l}\text { waste dumps, spoil heaps, } \\
\text { rubble areas }\end{array}$ & $\begin{array}{l}\text { one-time destruction } \\
\text { of biocenosis with } \\
\text { contemporaneous covering } \\
\text { of biotope with foreign } \\
\text { material }\end{array}$ & & \multirow[t]{2}{*}{$>23 \%$} & \multirow[t]{2}{*}{$>40 \%$} \\
\hline & $\begin{array}{l}\text { partly built-up areas (e.g. } \\
\text { paved paths, gravel tracks) }\end{array}$ & $\begin{array}{l}\text { biocenoses severely } \\
\text { decimated; biotope changes } \\
\text { significantly over the long } \\
\text { period of time }\end{array}$ & & & \\
\hline \multirow{2}{*}{ metahemerobic } & contaminated ecosystems & biocenosis destroyed & \multirow{2}{*}{$\begin{array}{l}\text { ecosystems } \\
\text { contaminated or treated } \\
\text { with biocides; intact } \\
\text { buildings and their } \\
\text { interiors }\end{array}$} & \multirow[b]{2}{*}{-} & \multirow[b]{2}{*}{ - } \\
\hline & $\begin{array}{l}\text { fully built-up ecosystems } \\
\text { (e.g. buildings, bituminous } \\
\text { surfaces/mats) }\end{array}$ & biocenosis destroyed & & & \\
\hline
\end{tabular}

Explanation: * - limit values valid for Berlin 


$\begin{array}{ccc}\text { Influencing soil-forming } & \text { Habitat change } & \text { Indicator of changes } \\ \text { processes } & \text { Change of edaphic } & \text { in diagnostic features } \\ \text { properties } & \text { compared to natural soil }\end{array}$

litter degradation, acidification or alkalization slight change in the supply of nutrients form of humus:

$\mathrm{Cl}-, \mathrm{SO}_{4^{-}}$, increase in soil solution humus form:

dystrophic, eutrophic decomposition, humification, partly
podsolization or pseudo-gleyation

slight change in the supply of nutrients, water or oxygen increased nutrient supply with $\mathrm{pH}$-changed availability of nutrient reserves; changed water source or $\mathrm{O}_{2}$ supply

as above; in addition, a small change in the rooting capacity in the topsoil

greatly increased supply (and discharge) of nutrients with reduced redox-dependent availability; increased root penetration of the subsoil; increased $\mathrm{O}_{2}$ supply or water supply lack of O-horizon; $\mathrm{pH}$ increase ecreased acidification,

as above; in addition: shallow turbation, erosion

as above; in addition: shallow turbation, erosion, rearrangements greatly increased supply (and discharge) of Rust stains; water and nutrients with reduced aeration $\quad \mathrm{V}_{\mathrm{Na}-}$ increase
Hydromorphing, humus accumulation, structural disintegration

\section{Ap-horizon;} $\mathrm{pH}$ increase

\section{formation of} cultosols with humus, homogeneous topsoil; $>30$ to $80 \mathrm{~cm}$; $\mathrm{pH}$ increase (partial) fossilization with sediment supply change in all habitat properties

covered with anthropogenic rock litter degradation and bioturbation greatly reduced reduced rooting and aeration

lack of O- and Ahhorizons sharp decline in biogenic processes pollutant dominance (decomposition, humification, bioturbation) greatly reduced or absent $\mathrm{CO}_{2}$ release 
Table 2. The structure of the paper entitled: Wandel von Flora und Vegetation in Mitteleuropa unter dem Einfluß des Menschen (Sukopp 1972) [Change of flora and vegetation in Central Europe under the influence of humans]

\section{Introduction*}

2. Human influence on flora

2.1. Plant migration under the influence of humans

2.1.1. Immigration period of the hemerochores

2.1.2. Immigration way of the hemerochores

2.1.3. Degree of naturalization

2.2. Influence of humans on taxa evolution in wild plants

2.3. Decline in ferns and flowering plants

2.3.1. General considerations

2.3.2. Examples from Central Europe

2.3.3. Causes of extinction

3. Human influence on vegetation

3.1. Decline in plant communities

3.2. Spread and formation of new plant communities

4. Outlook

Summary/Résume

Bibliography

The language describing anthropogenic changes in the flora of Europe has been developing since the half of the 19th centuries (e.g. Watson 1847; Candolle 1855; Thellung 1905, 1915, 1919, 1925; Linkola 1916). From the beginning of the 1960s, Sukopp participated lively in this discussion. He wrote many times, among others, on the classification of flora taking into account the role of humans in its shaping. This problem was presented in a particularly interesting way in the work published jointly with Scholz at the end of the 20th century (Sukopp \& Scholz 1997). In the context of classifications proposed by other authors (Kornaś 1968, 1981; Jackowiak 1990, 1993; Mirek 1991; Pyšek 1995; Pyšek et al. 2004), attention is drawn to the consideration of the group of native species occurring only in natural habitats (Ahemerophytes) and separation of the Indigenophyta anthropogena (Anecophytes) group (Fig. 1). The introduction to this classification of native species not adaptable to anthropogenic factors, at the same time, draws attention to the less frequently discussed problem of apophytes. The separation of anecophytes ('homeless plants'), in turn, draws attention to the relatively rarely studied phenomenon of plant evolution in historical time. More about the evolution of concepts and terms related to plant invasion can be found in the study by Kowarik and Pyšek (2012).

\section{Synthetic works and empirical studies}

The creative output of Herbert Sukopp in the field of anthropogenic changes of plant cover is characterized by a thematic scope and a wealth of review and theoretical works illustrated with many examples from his own

\begin{tabular}{|c|}
\hline \\
\hline native: \\
Indigenous plants \\
\hline
\end{tabular}

non-native:

Hemerochorous plants

according to the degree of naturalization
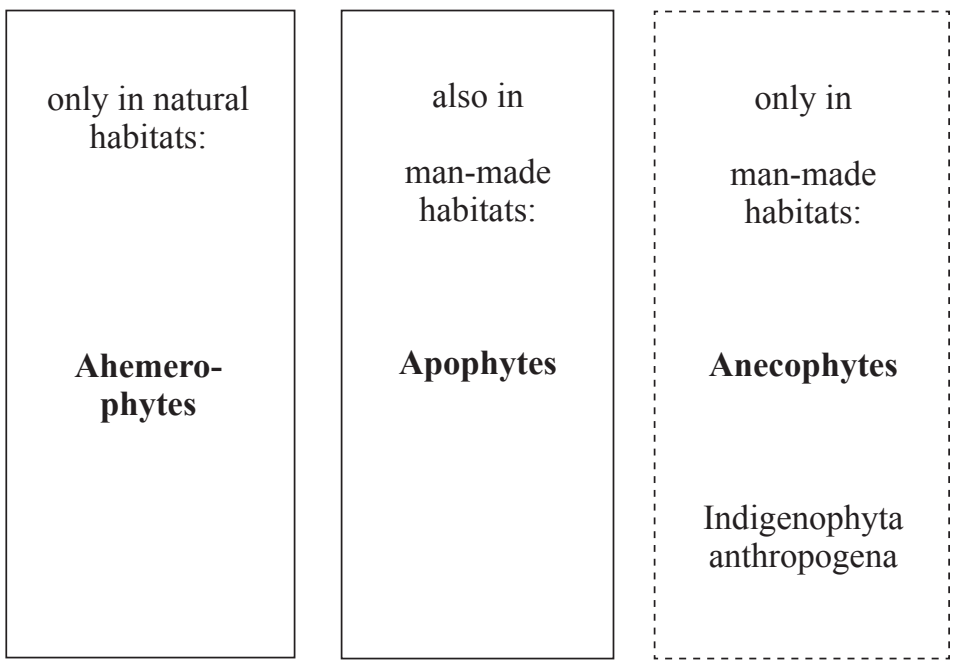

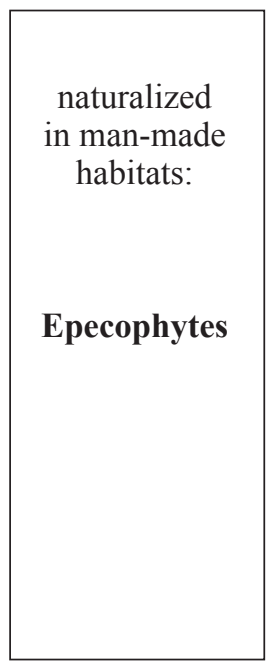

naturalized in natural or semi-natural habitats:

Agriophytes

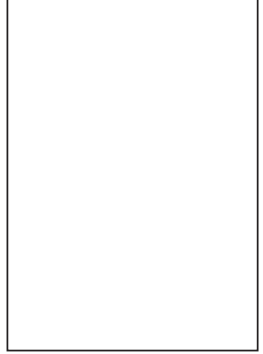

Fig. 1. Classification of the flora of certain area according to indigenous status or degree of naturalization (Sukopp \& Scholz 1997) 
Table 3. A representative list of Sukopp's review and multi-thematic works on anthropogenic changes of flora and vegetation

\begin{tabular}{|c|c|c|}
\hline Year & Titles of the papers & Co-authors \\
\hline 1967 & Flora and vegetation changes in Central Europe during the last centuries (G) & - \\
\hline $1968 \mathrm{a}$ & $\begin{array}{l}\text { Human influence on vegetation and on the terminology of anthropogenic vegetation } \\
\text { types }(G)\end{array}$ & - \\
\hline 1969 & Human influence on vegetation $(G)$ & - \\
\hline 1972 & Man-made changes to flora and vegetation in Central Europe $(G)$ & - \\
\hline 1976 & Ecological significance of anthropogenic soil changes $(G)$ & Blume H-P. \\
\hline 1976 & Dynamics and constancy in the flora of the Federal Republic of Germany (G) & - \\
\hline 1979 & Changes of flora and vegetation in Central Europe during the last centuries (G) & - \\
\hline 1981 & Changes of flora and vegetation in agricultural landscapes $(\mathrm{G})$ & - \\
\hline 1986 & Consideration of neophytes in red lists of endangered species $(\mathrm{G})$ & Kowarik I. \\
\hline 1987 & $\begin{array}{l}\text { Extinction and naturalization of plant species as related to ecosystem structure and } \\
\text { function }(E)\end{array}$ & Trepl L. \\
\hline 2000 & Changing climates and the effects on vegetation in central European cities (E) & Wurzel A. \\
\hline 2000 & $\begin{array}{l}\text { On the importance of apophytia, hemerochory and anecophytia for biological } \\
\text { diversity }(G)\end{array}$ & Kowarik I. \\
\hline 2003 & The effects of climate change on the vegetation of central European cities (E) & Wurzel A. \\
\hline 2007 & Dynamism and constancy in the development of cultural landscapes (G) & - \\
\hline 2018 & $\begin{array}{l}\text { Red list and total species list of the established fern and flowering plants of Berlin } \\
\text { (G) }\end{array}$ & $\begin{array}{l}\text { Seitz B., Ristow } \\
\text { M., Meißner J., } \\
\text { Machatzi B. }\end{array}$ \\
\hline
\end{tabular}

Explanations: G - original in German (translation BJ), E - original in English

research. Taking into account the leading topics of the publications, they can be divided into four main groups: (1) overview-theoretical and multi-topic (Table 3); (2) related to the introduction and naturalization of species (Table 4), (3) devoted to the spread of native species to anthropogenic habitats (Table 5), and (4) focused on species extinction and decline (Table 6). It is neither a complete nor a disjunctive classification, but it shows that Professor Sukopp has repeatedly discussed the key issues concerning the relationship between humans and flora and vegetation.

It is also worth noting that throughout his research career, he dealt with the biology and ecology of plant species related to human activity in various ways (Table 7). A list of these species includes both apophytes (Campanula rapunculoides, Humulus lupulus, Veronica sublobata, Viscum album) and species of foreign origin: archaeophyte (Poa bulbosa) and neophytes (Chenopodium botrys, Impatiens glandulifera, Inula graveolens, Parietaria pensylvanica, Pterocarya fraxinifolia, Reynoutria japonica, $R$. sacchalinensis, Rumex triangulivalvis, Sagittaria latifolia, Veronica filiformis).

\section{Dissemination of Sukopp's concepts on anthropogenic changes in flora and vegetation}

A large part of Sukopp's scientific activity took place before the era of total digitization of scientific information and the unification of language of publications. The works were usually sent directly to the most interested researchers in the form of offprints, often with the author's personal dedication. For these reasons, the contemporary databases of scientific knowledge hardly reflect the influence of the authors of this epoch on the development of science. All the more, it is worth paying attention to the very wide scope of the impact of Sukopp's works, confirmed by data from leading scientific information databases (Web of Science; Scopus, Google Scholar). This applies both to the publications on urban ecology, which was already pointed out by Kowarik (2020), and to the works related to anthropogenic changes in plant cover.

At least 287 works by Sukopp are cited in the publications indexed in the Scopus database. The total number of citations is over 3046; 28 publications were cited more than 28 times. At least 221 works by Sukopp are cited in the publications indexed in the Web of Science. The total number of citations is over 2698; 25 publications were cited more than 25 times. In total, 307 works are cited in both databases. In order to obtain full information about their dissemination, they were identified in the Google Scholar database. They have been found to be cited 8229 times; 44 of these were cited at least 44 times.

Among the most frequently cited works in the Scopus database, apart from urban ecology, there are 25 
Table 4. A representative list of Sukopp's works on the introduction and naturalization of plant species

\begin{tabular}{|c|c|c|}
\hline Year & Titles of the papers & Co-authors \\
\hline $1962 / 1966 a$ & Neophytes in natural plant communities in Central Europe $(G, G)$ & - \\
\hline 1980 & On the history of the spread of plants over the past hundred years $(G)$ & - \\
\hline $1986 \mathrm{a}$ & Ecological effects of introducing of new plant species $(\mathrm{G})$ & Kowarik I. \\
\hline $1986 b$ & Unexpected effects of newly introduced plant species (G) & Kowarik I. \\
\hline 1992 & Agriophytes in the vegetation of Central Europe $(\mathrm{G})$ & Lohmeyer W. \\
\hline 1993 & $\begin{array}{l}\text { On the importance of the introduction and naturalization of plants and } \\
\text { animals for the future of biodiversity }(\mathrm{G})\end{array}$ & Trepl L. \\
\hline $1993 \mathrm{a}$ & $\begin{array}{l}\text { The model of the introduction and naturalization of alien species. A } \\
\text { contribution to the discussion about the release of genetically modified } \\
\text { crops. (G) }\end{array}$ & Sukopp U. \\
\hline $1993 b$ & $\begin{array}{l}\text { Ecological long-term effects of cultigens becoming feral and of } \\
\text { naturalization of non-native species }(\mathrm{E})\end{array}$ & Sukopp U. \\
\hline 1993 & Transgenic organisms: risk assessment of deliberate release (E) & Bartsch D., Sukopp U. \\
\hline $1994 \mathrm{a}$ & Ecological long-time effects of the growing wild of crop plants (E) & Sukopp U. \\
\hline $1994 b$ & The model of the introduction and naturalization of non-native plants $(\mathrm{G})$ & Sukopp U. \\
\hline $1994 \mathrm{c}$ & Long-term ecological effects of the naturalization of crops $(\mathrm{G})$ & Sukopp U. \\
\hline 1995 & $\begin{array}{l}\text { Ecological models in accompanying research on the release of transgenic } \\
\text { crops }(\mathrm{G})\end{array}$ & Sukopp U. \\
\hline 1995 & Neophytia and Neophytism (G) & \\
\hline 1997 & Origin of the weeds $(\mathrm{G})$ & Scholz H. \\
\hline 1996 & Green genetic engineering in conflict $(\mathrm{G})$ & $\begin{array}{l}\text { Van Den Daele W., } \\
\text { Pühler A. }\end{array}$ \\
\hline 1997 & $\begin{array}{l}\text { Accompanying ecological research and permanent monitoring in connection } \\
\text { with the release and placing on the market of genetically modified crops }(\mathrm{G})\end{array}$ & Sukopp U. \\
\hline 1997 & Long-term ecological monitoring of genetically modified crops (G) & Sukopp U. \\
\hline 1997 & $\begin{array}{l}\text { Transgenic Herbidcide-Resistant Crops: A Participatory Technology } \\
\text { Assessment (E) }\end{array}$ & $\begin{array}{l}\text { Van Den Daele, W., } \\
\text { Pühler A., }\end{array}$ \\
\hline $1998 \mathrm{a}$ & On the study of anthropogenic plant migrations in central Europe (E) & - \\
\hline 2001 & Agriophytes in the vegetation of Central Europe. $1^{\text {st }}$ supplement $(\mathrm{G})$ & Lohmeyer W. \\
\hline $2001 \mathrm{a}$ & Neophytes (G) & - \\
\hline $2001 b$ & $\begin{array}{l}\text { Development of the cultivated landscapes of Central Europe and ecological } \\
\text { risk assessment of the cultivation of transgenic crops }(G)\end{array}$ & - \\
\hline 2001 & Ornamental plants: Future potential or risk for biodiversity in cities? (E) & Maurer U. \\
\hline 2002 & To expand biological diversity in cultivated landscapes $(\mathrm{G})$ & Kowarik I. \\
\hline 2006 & $\begin{array}{l}\text { Ecological range of invasive plant species in Central European pine (Pinus } \\
\text { sylvestris L.) forests (E) }\end{array}$ & $\begin{array}{l}\text { Winter K., Kreyer D., } \\
\text { Maurer U., Schmitz S., } \\
\text { Vater, G., Wirth P. }\end{array}$ \\
\hline 2008 & The plants of horticultural areas and their agriophytic occurrence $(\mathrm{G})$ & Kowarik I. \\
\hline 2016 & $\begin{array}{l}\text { Influence of different landscape design styles on plant invasions in Central } \\
\text { Europe (E) }\end{array}$ & Müller N. \\
\hline
\end{tabular}

Explanations: G - original in German (translation BJ), E - original in English

publications on anthropogenic changes in plant cover. In total, they were cited 956 times. The same works in the Web of Science database have 802 citations, while in Google Scholar - 2680 citations.

The first citation in the Scopus database comes from 1971 and refers to an article devoted to neophytes occurring in natural plant communities of Central Europe (Sukopp 1962). Since 1996, the number of citations has clearly increased, including all the previously published and discussed works in the field of anthropogenic changes in flora and vegetation (Fig. 2 ). The work on changes in the flora and vegetation of Central Europe under the influence of humans has been regularly cited since its publication in 1972 (Sukopp 1972). The list of the most cited works includes publications representing the main research directions undertaken by Sukopp in the area of anthropogenic changes in plant cover. They include both theoretical and review works as well as empirical publications (Table 8). 
Table 5. Sukopp's works on the spread of native species to anthropogenic habitats

\begin{tabular}{cc}
\cline { 2 - 2 } Year & \multicolumn{1}{c}{ Titles of the papers } \\
\hline 2006 & Apophytes in the flora of Central Europe (E) \\
2008 & Apophytes in the flora of Central Europe (G) \\
\hline Explanations: G - original in German (translation-BJ), E- original in English
\end{tabular}

Table 6. A representative list of Sukopp's works on extinction and decline of species

\begin{tabular}{|c|c|c|}
\hline Year & Titles of the papers & Co-authors \\
\hline $1966 b$ & Loss of the Berlin flora during the last hundred years $(\mathrm{G})$ & - \\
\hline $1971 b$ & Effects of man, especially recreational activities, on littoral macrophytes (E) & - \\
\hline $1971 \mathrm{c}$ & On the decline of ferns and flowering plants $(\mathrm{G})$ & - \\
\hline 1972 & $\begin{array}{l}\text { The species of fern and flowering plants endangered in the Federal Republic of } \\
\text { Germany }(G)\end{array}$ & $\begin{array}{l}\text { Lohmeyer W., Müller T., } \\
\text { Pritzer E. }\end{array}$ \\
\hline 1974 & $\begin{array}{l}\text { "Red List" of the Federal Republic of Germany endangered species of fern and } \\
\text { flowering plants }\left(1^{\text {st }} \text { version) }(G)\right.\end{array}$ & - \\
\hline 1975 & Reeds under intense urban influence $(G)$ & Markstein B., Trepl L. \\
\hline 1978 & $\begin{array}{l}\text { Evaluation of the red list of endangered ferns and flowering plants of the Federal } \\
\text { Republic of Germany for the protection of species and biotopes }(\mathrm{G})\end{array}$ & $\begin{array}{l}\text { Trautmann W., Komeck } \\
\text { D. }\end{array}$ \\
\hline 1981 & $\begin{array}{l}\text { Changes in reed beds and plants as indicators of water use illustrated using the } \\
\text { example of the Havel in Berlin }(G)\end{array}$ & Markstein B., \\
\hline 1981 & Causes of the decline of threatened plants in the Federal Republic of Germany (E) & Trautmann W. \\
\hline 1982 & Red list of endangered plants and animals in Berlin (West) $(G)$ & Elvers H. \\
\hline 1984 & Red list of endangered animals and plants in the Federal Republic of Germany (G) & $\begin{array}{l}\text { Blab J., Nowak E., } \\
\text { Trautmann W., }\end{array}$ \\
\hline 1988 & $\begin{array}{l}\text { Red list of ferns and flowering plants that are extinct, lost and endangered in } \\
\text { the Federal Republic of Germany and their evaluation for species and biotope } \\
\text { protection }(\mathrm{G})\end{array}$ & Korneck D., \\
\hline 1989 & Changes of the reed beds along the Berlin Havel, 1962-1987 (E) & Markstein B. \\
\hline 1989 & Reed. A common species in decline $(\mathrm{E})$ & Den Hartog C., Květ J., \\
\hline 1990 & Red lists of endangered plants and animals in Berlin $(\mathrm{G})$ & Auhagen A., Plateu R., \\
\hline 1994 & Biological-ecological basis for the protection of endangered segetal plants $(G)$ & Schneider C., Sukopp U. \\
\hline 2004 & Human-caused impact on preserved vegetation $(\mathrm{E})$ & - \\
\hline
\end{tabular}

Explanations: G - original in German (translation BJ), E - original in English

Table 7. List of single plant taxa described in the works of Sukopp et al.

\begin{tabular}{|c|c|c|c|}
\hline Year & Taxa name & Status & Co-authors \\
\hline 1964 & Parietaria pensylvanica Mühlenb. ex Willd. & epekophyte & Scholz H. \\
\hline 1965 & Rumex triangulivalvis (Danser) Rech. fil. & epekophyte & Scholz H. \\
\hline 1968 & Poa bulbosa L. & archeophyte & Scholz H. \\
\hline $1968 \mathrm{c}$ & Viscum album $\mathrm{L}$. & apophyte & - \\
\hline 1970 & Sagittaria latifolia Willd. & agriophyte & - \\
\hline 1971 & Chenopodium botrys L. & epekophyte & Bornkamm R. \\
\hline $1971 \mathrm{a}$ & Chenopodium botrys L. & epekophyte & - \\
\hline 1987 & Humulus lupulus L. & apophyte & Kowarik I. \\
\hline 1988 & Reynoutria japonica Houtt. & epekophyte & Sukopp U. \\
\hline 1991 & $\begin{array}{l}\text { Reynoutria japonica Houtt. } \\
\text { Reynoutria sacchalinensis (F. Schmidt Petrop.) Nakai }\end{array}$ & epekophyte & Schick B \\
\hline 1991 & Chenopodium botrys L. and Inula graveolens L. & epekophyte & Dettmarr J. \\
\hline 1993 & Veronica filiformis Smith & neophyte & Müller N. \\
\hline 1993 & Veronica sublobata M. Fischer & apophyte & - \\
\hline 1993 & Reynoutria sp. & epekophyte & - \\
\hline 1995 & Reynoutria sacchalinensis (F. Schmidt Petrop.) Nakai & epekophyte & Starfinger U. \\
\hline 1996 & Campanula rapunculoides $\mathrm{L}$. & apophyte & Langer A. \\
\hline 2004 & Impatiens glandulifera Royle & neophyte & Sukopp U. \\
\hline 2015 & Pterocarya fraxinifolia [Lam. ex Poir.] Spach & neophyte & R. Böcker R., Brande A. \\
\hline
\end{tabular}


Table 8. The list of the most frequently cited publications by H. Sukopp on anthropogenic changes in flora and vegetation

\begin{tabular}{|c|c|c|c|c|c|}
\hline Titles of the publications * & Authors & Year & Scopus & WoS & GS \\
\hline $\begin{array}{l}\text { Agriophyten in der Vegetation Mitteleuropas } \\
\text { [Agriophytes in the vegetation of Central Europe] }\end{array}$ & Lohmeyer W., Sukopp H. & 1992 & 107 & 80 & 269 \\
\hline $\begin{array}{l}\text { Wandel von Flora und Vegetation in Mitteleuropa unter dem } \\
\text { Einfluß des Menschen } \\
\text { [Man-made changes to flora and vegetation in Central Europe] }\end{array}$ & Sukopp H. & 1972 & 99 & 95 & 277 \\
\hline Human-caused impact on preserved vegetation & Sukopp H. & 2004 & 97 & 104 & 199 \\
\hline Reed. A common species in decline & Den Hartog C., Květ J., Sukopp H. & 1989 & 71 & 66 & 115 \\
\hline $\begin{array}{l}\text { Ökologische Bedeutung anthropogener Bodenveränderungen } \\
\text { [Ecological significance of anthropogenic soil changes] }\end{array}$ & Blume H.-P., Sukopp H. & 1976 & 64 & 51 & 179 \\
\hline $\begin{array}{l}\text { Rote Liste der in der Bundesrepublik Deutschland } \\
\text { ausgestorbenen, verschollenen und gefährdeten Farn- und } \\
\text { Blütenpflanzen und ihre Auswertung für den Arten- und } \\
\text { Biotopschutz } \\
\text { [Red list of the extinct, lost and endangered fern and flowering } \\
\text { plants in the Federal Republic of Germany and their evaluation } \\
\text { for species and biotope protection] }\end{array}$ & Korneck D., Sukopp H. & 1988 & 61 & 28 & 217 \\
\hline $\begin{array}{l}\text { Biologisch-ökologische Grundlagen des Schutzes gefährdeter } \\
\text { Segetalpflanzen } \\
\text { [Biological-ecological basis for the protection of endangered } \\
\text { segetal plants] }\end{array}$ & $\begin{array}{l}\text { Schneider C., Sukopp U., Sukopp } \\
\text { H. }\end{array}$ & 1994 & 56 & 30 & 107 \\
\hline $\begin{array}{l}\text { Der Einfluß des Menschen auf die Vegetation } \\
\text { [Human influence on vegetation] }\end{array}$ & Sukopp H. & 1969 & 52 & 60 & 179 \\
\hline $\begin{array}{l}\text { Rote Liste der Gefährdeten Tiere und Pflanzen in der } \\
\text { Bundesrepublik Deutschland } \\
\text { [Red list of endangered animals and plants in the Federal } \\
\text { Republic of Germany] }\end{array}$ & $\begin{array}{l}\text { Blab J., Nowak E., Trautmann W., } \\
\text { Sukopp H. }\end{array}$ & 1984 & 44 & 25 & 252 \\
\hline $\begin{array}{l}\text { Dynamik und Konstanz in der Flora der Bundesrepublik } \\
\text { Deutschland } \\
\text { [Dynamism and constancy in the flora of the Federal Republic } \\
\text { of Germany] }\end{array}$ & Sukopp H. & 1976 & 34 & 46 & 119 \\
\hline Changes of the reed beds along the Berlin Havel, 1962-1987 &., $\mathrm{M}$ & 1989 & 29 & 24 & 46 \\
\hline $\begin{array}{l}\text { Reynoutria sachalinensis in Europe and in the Far East: A } \\
\text { comparison of the species ecology in its native and adventive } \\
\text { distribution range }\end{array}$ & Sukopp H., Starfinger U. & 1995 & 28 & 28 & 58 \\
\hline $\begin{array}{l}\text { Extinction and naturalization of plant species as related to } \\
\text { ecosystem structure and function }\end{array}$ & Sukopp H., Trepl L. & 1987 & 23 & 18 & 59 \\
\hline $\begin{array}{l}\text { Grüne Gentechnik im Widerstreit } \\
\text { [Green genetic engineering in conflict] }\end{array}$ & $\begin{array}{l}\text { Van den Daele W., Pühler A., } \\
\text { Sukopp H. }\end{array}$ & 1996 & 22 & 3 & 85 \\
\hline $\begin{array}{l}\text { Transgenic Herbicide-Resistant Crops: A Participatory } \\
\text { Technology Assessment }\end{array}$ & $\begin{array}{l}\text { Van Den Daele W., Pühler A., } \\
\text { Sukopp H. }\end{array}$ & 1997 & 22 & 8 & 27 \\
\hline $\begin{array}{l}\text { Effects of man, especially recreational activities, on littoral } \\
\text { macrophytes }\end{array}$ & Sukopp H. & 1971 & 19 & 20 & 43 \\
\hline $\begin{array}{l}\text { Beiträge zur Ökologie von Chenopodium botrys L. } \\
\text { [Contributions to the ecology of Chenopodium botrys L.] }\end{array}$ & Sukopp H. & 1971 & 17 & 10 & 41 \\
\hline Herkunft der Unkräuter [Origin of the weeds] & H., $\mathrm{Scl}$ & 1997 & 17 & 9 & 50 \\
\hline On the & & 1998 & 17 & 18 & 38 \\
\hline $\begin{array}{l}\text { Ecological long-term effects of cultigens becoming feral and of } \\
\text { naturalization of non-native species }\end{array}$ & Sukopp H., Sukopp, U. & 1993 & 16 & 22 & 53 \\
\hline $\begin{array}{l}\text { Auswertung der Roten Liste gefährdeter Farn- und } \\
\text { Blütenpflanzen der Bundesrepublik Deutschland für den Arten- } \\
\text { und Biotopschutz. } \\
\text { [Evaluation of the Red List of Endangered Ferns and Flowering } \\
\text { Plants of the Federal Republic of Germany for the protection of } \\
\text { species and biotopes] }\end{array}$ & $\begin{array}{l}\text { Sukopp H., Trautmann W., } \\
\text { Korneck D. }\end{array}$ & 1978 & 16 & 15 & 79 \\
\hline $\begin{array}{l}\text { Neophyten in natürlichen Pflanzengesellschaften Mitteleuropas } \\
\text { [Neophytes in natural plant communities in Central Europe] }\end{array}$ & Sukopp H. & 1962 & 15 & 19 & 78 \\
\hline Reynoutria japonica Houtt. in Japan und in Europa & , Sukopp U. & 1988 & 12 & 2 & 49 \\
\hline Apophytes in the flora of Central Europe & Sukopp H. & 2006 & 11 & 10 & 25 \\
\hline \multirow[t]{2}{*}{ Introduction of plants with special regard to cultigens running wild } & Bartsch D., Sukopp H., Sukopp U. & 1993 & 10 & 11 & 36 \\
\hline & & & 956 & 802 & 2680 \\
\hline
\end{tabular}




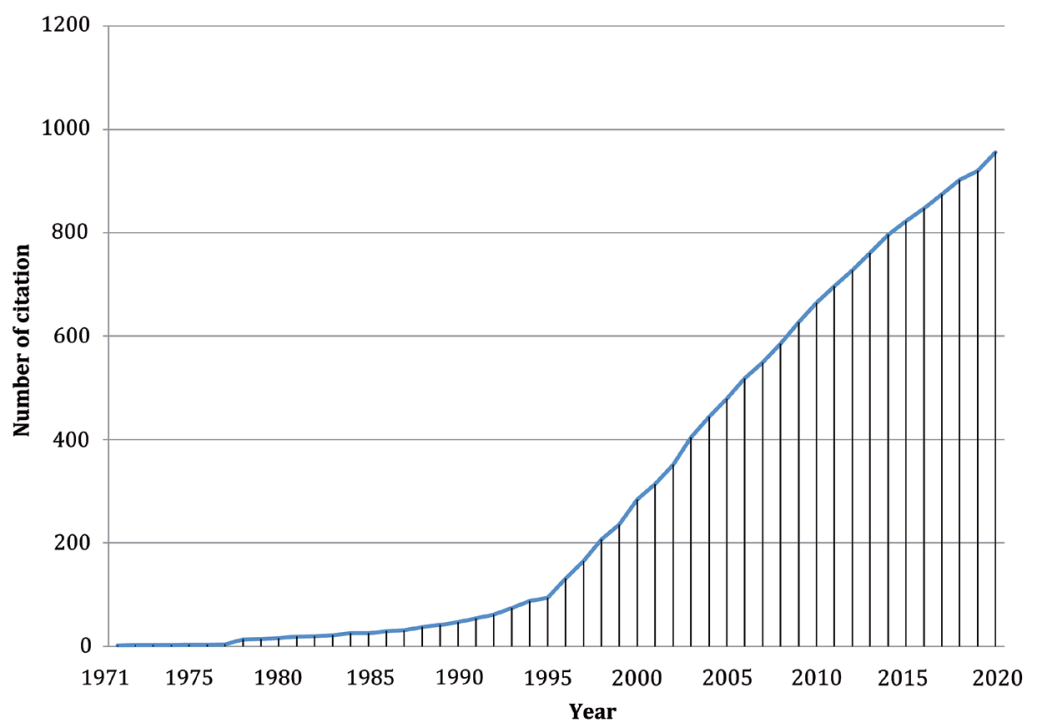

Fig. 2. Increase in the number of citations of Sukopp's works on anthropogenic changes of plant cover in the years 1971-2020 (the list of cited works is presented in Table 8)

Using the affiliation of the authors of citations as an indicator of geographical spread of 25 analyzed publications, it can be concluded that Sukopp's concepts concerning human influence on flora and vegetation are known in at least 51 countries located on 5 continents (Fig. 3).

\section{Dynamism and constancy: two words instead of conclusions}

In 1995, there was published a collective work entitled "Dynamik und Konstanz. Sukopp Festschrift" [Dynamism and constancy. Sukopp's Jubilee Issue]

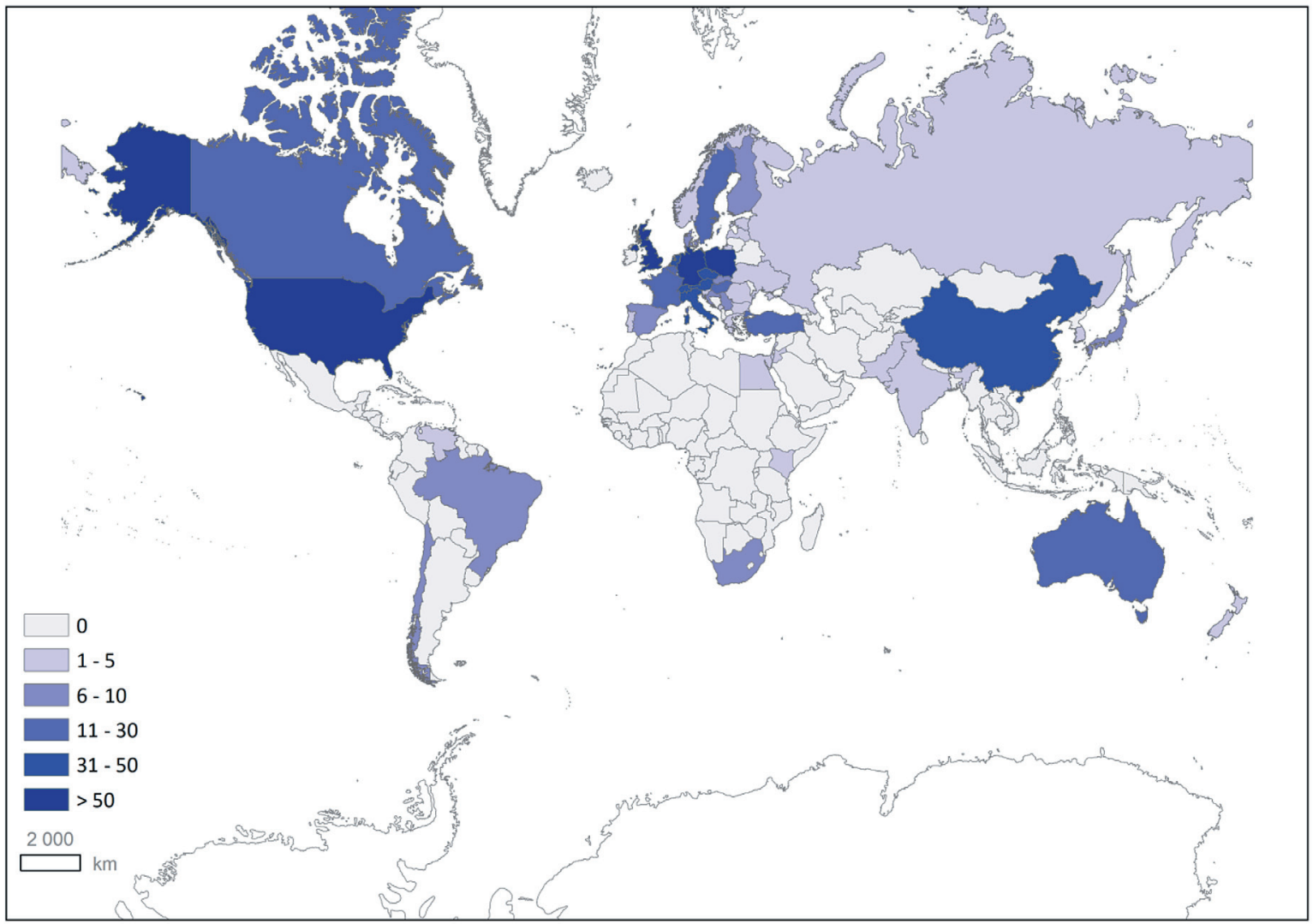

Fig. 3. The impact of Sukopp's works on anthropogenic changes in flora and vegetation measured by the number of authors of publications citing his works (the list of cited works is presented in Table 8) 
(Kowarik et al. 1995). Following this event, I wrote a review in which I recommended this publication to botanists in Poland (Jackowiak 1997). Below I am quoting a fragment of this text that, in my opinion, is still relevant:

"The title of the work 'Dynamik und Konstanz' proposed by the editors is a perfect synthesis of both Professor Sukopp's scientific achievements and his personality traits. ... Indeed, the main subject of the Professor's interest and research were and still are the broadly understood transformations of the plant world under the influence of human activity. They concern both the phenomena accompanying the extinction of species and the spread of plants, in particular alien newcomers, but also taxa of native origin (apophytes). At the same time, it is difficult not to agree that 'dynamics and constancy', two fundamentally opposite features, perfectly apply to the person of a Jubilarian. The extraordinary dynamics of scientific activity and the persistence of interests, with creative reference to the problems started in the 1950 s or 1960 s, is probably the key to understanding the Professor's achievements."

As already mentioned, in 1998, Polish botanists dedicated to Professor Sukopp a collective work entitled "Synanthropization of plant cover in new Polish research" (Faliński et al. 1998). Finally, I would like to recall three fragments from the introduction that enrich the scientific portrait of Professor Sukopp with colors that go beyond the range of strictly scientific achievements:

"Prof. H. Sukopp has maintained contacts with virtually every scientific centre in Poland that engages in research on the synanthropization of plant cover. He has provided invitations to lectures and scientific conferences in West Berlin, offered material assistance and accommodation and even hosted visitors in own home. No less than 20 people from Poland took advantage of this help to travel to Berlin and Germany, sometimes a number of times. Particularly unstinting help was afforded Polish participants at the World Botanical Congress in 1987, as well as the 1980 international conference on urban ecology. He also supplied literature, regularly sending his publications. However, perhaps the most important fact is that he has valued the output of Polish science and promoted it around the world" (Olaczek 1998: 5).

"I am personally indebted to Professor Sukopp for bringing my ideas on synanthropization into circulation abroad. ... I would also like to emphasize his particular interest in Polish research into the synanthropization of plant cover and the kindness he has shown to the research themselves..." (Janusz Bogdan Faliński in: Olaczek 1998: 5).

"I have been in touch with Professor Sukopp for a great many years. My file of exchanges includes 193 references to the Professor... [who] has cited our work and that of other Polish authors" (Anna MedweckaKornaś in: Olaczek 1998: 5).

Acknowledgments: I am grateful to Professor Ingo Kowarik for reading the manuscript and very valuable comments. I thank Mrs. Elżbieta Obarska, MA, for the linguistic verification of the text. I would like also to thank Dr. Maciej Nowak for preparing the map.

\section{References}

Auhagen A., Plateu R. \& Sukopp H. 1990. Rote Listen der gefährdeten Pflanzen und Tiere in Berlin. Landschaftsentwicklung und Umweltforschung 6: 57-88.

Bartsch D., Sukopp H. \& Sukopp U. 1993. Transgenic organisms: risk assessment of deliberate release. In: WÖHRMANN K. \& TOMIUK J. (eds.). Introduction of plants with special regard to cultigens running wild. Transgenic Organisms, Risk Assessment of Deliberate Release, pp. 135-151. Birkhäuser Verlag AG.

BEHRE K-E. 1998. The role of man in European vegetation history. In: Huntley B. \& T. III WebB (eds.). Vegetation History. Handbook of vegetation science 7: 633-672. Springer, Dordrecht.

Blab J., Nowak E., Trautmann W. \& Sukopp H. 1984. Rote Liste der Gefährdeten Tiere und Pflanzen in der Bundesrepublik Deutschland. Kilda-Verlag 1: 1-270.
Blume H. P. \& Sukopp H. 1976. Ökologische Bedeutung anthropogener Bodenveränderungen. Schriftenreihe für Vegetationskunde 10: 75-89.

Bornkamm R. \& Sukopp H. 1971. Beiträge zur Ökologie von Chenopodium botrys L. VI. Die ökologische Konstitution von Chenopodium botrys. Verh. Bot. Ver. Prov. Brandenburg 108: 64-74.

Candolle A. de 1855. Géographie botanique raisonné. Paris,

Den Hartog C., Květ J. \& Sukopp H. 1989. Reed. A common species in decline. Aquat Bot 35(1): 1-4.

Dettmarr J. \& Sukopp H. 1991. Vorkommen und Gesellschaftsanschluss von Chenopodium botrys L. und Inula graveolens (L.) Desf. im Ruhrgebiet (Westdeutschland) sowie im regionalen Vergleich. Tuexenia 11: 49-65.

FAliński J. B., AdAmowski W. \& Jackowiak B. (eds.). 1998. Synanthropization of plant cover in new Polish 
Research. Phytocoenosis 10 (N.S.) Suppl. Cartogr. Geobot. 9: 1-279.

JACKOWIAK B. 1990. Antropogeniczne przemiany flory roślin naczyniowych Poznania [Anthropogenic changes of the flora of vascular plants of Poznań]. Wyd. Nauk. UAM, seria Biologia, 42, 232 pp. Poznań.

JACKOWIAK B. 1993. Atlas of distribution of vascular plants in Poznań. Publications of the Department of Plant Taxonomy of the Adam Mickiewicz University in Poznań 2: 1-409.

JACKOWIAK B. 1997. Review of the work: Kowarik I., Starfinger U. \& Trepl L. (eds.) 1995. Dynamik und Konstanz. Sukopp-Festschrift, 27, 489 pp. Fragm. Flor. Geobot. Ser. Polonica 4: 406.

JALAS J. 1953. Hemerokorit ja hemerobit. Luonnon Tutkija. 57: $12-16$.

JALAS J. 1955. Hemerobe und hemerochore Pflanzenarten. Ein terminologischer Reformversuch. Acta Societas Flora Fauna Fennica 72: 1-15.

Kolkwitz R. 1950. Ökologie der Saprobien. Schr.-R. Ver. Waset-, Boden-, Lufthyg. 4: 1-64.

KoRNAŚ J. 1968. Geograficzno-historyczna klasyfikacja roślin synantropijnych [A geographical-historical classification of synanthropic plants]. Mater. Zakł. Fitos. Stos. UW 25: 33-41.

KoRnAŚ J. 1981. Oddziaływanie człowieka na florę - mechanizmy i konsekwencje [Human influence on flora - mechanisms and consequences]. Wiad. Bot. 25(3): 165-182.

Korneck D., Lohmeyer W., Trautmann W. \& Sukopp 1977. Red list of ferns and flowering plants (Pteridophyta et Spermatophyta). Rote Liste der gefährdeten Tierre und Pflanzen in der Bundesrepublik Deutschland.

KoRneck D. \& Sukopp H. 1988. Rote Liste der in der Bundesrepublik Deutschland ausgestorbenen, verschollenen und gefährdeten Farn- und Blütenpflanzen und ihre Auswertung für den Arten- und Biotopschutz. Schriftenreihe für Vegetationskunde 19, 210 pp.

KowARIK I. 1988. Zum Einfluss des Menschen auf Flora und Vegetation. Theoretische Konzepte und ein Quantifizierungsansatz am Beispiel von Berlin (West). Landschaftsentwicklung Umweltforschung 56: 1-280.

KOWARIK I. 2020. Herbert Sukopp - an inspiring pioneer in the field of urban ecology. Urban Ecosystems 23: 445-455.

KowARIK I. \& PYŠEK P. 2012. The first steps towards unifying concepts in invasion ecology were made one hundred years ago: revisiting the work of the Swiss botanist Albert Thellung. Divers Distrib 18(12): 1243-1252.

Kowarik I., Starfinger U. \& Trepl L. (eds.). 1995. Dynamik und Konstanz. Zum 65. Geburtstag von Herbert Sukopp. Dynamik und Konstanz. Festschrift für Herbert Sukopp. Schriftenreihe für Vegetationskunde 27: 1-489.

Kowarik I. \& Sukopp H. 1986a. Ökologische Folgen der Einführung neuer Pflanzenarten. Gentechnologie 10: 111-135.

KowARIK I. \& SuKopP H. 1986b. Unerwartete Auswirkungen neu eingeführter Pflanzenarten. Universitas 41(483): 828-845.
KowArIK I. \& SuKopp H. 2000. Zur Bedeutung von Apophytie, Hemerochorie und Anökophytie für die biologische Vielfalt. Schriftenreihe Vegetationskunde 32: 167-182.

LinKola K. 1916. Studien über den Einfluss der Kultur auf die Flora in den Gegenden nördlich vem Ladegasee. I. Allgemeiner Teil. Acta Soc. Faun. Flor. Fenn. 45: $1-432$.

Lohmeyer W. \& Sukopp H. 2001. Agriophyten in der Vegetation Mitteleuropas. 1. Nachtrag. In: D. Brandes (ed.). Adventivpflanzen. Beiträge zu Biologie, Vorkommen und Ausbreitungsdynamik von Archäophyten und Neophyten in Mitteleuropa. Braunschweiger Geobotanische Arbeiten 8: 179-220.

Lohmeyer W. \& Sukopp H. 1992. Agriophyten in der Vegetation Mitteleuropas. Schriftenreihe für Vegetationskunde 25: 1-185.

Maubach C. 1995. Verzeichnis der Schriften von Herbert Sukopp 1955-1994. Schriftenreihe für Vegetationskunde (Festschrift Sukopp) 27: 467-489.

Mirek Z. 1991. Classification of synanthropic plants in relation to vegetation changes during the Holocene. Veröffentlichungen des Geobotanischen Instituts der ETH, Stiftung Rübel in Zürich 106: 122-132. Zürich.

Müller N. \& Sukopp H. 1991. Synathrope Ausbreitung und Vergesellschaftung des Fadenförmigen Ehrenpreises - Veronica filiformis Sm. Tuexenia 13: 399-413.

Müller N. \& Sukopp H. 2016. Influence of different landscape design styles on plant invasions in Central Europe. Landscape and Ecological Engineering 12(1): 151-169.

Olaczek R. 1998. Professor Dr. Herbert Sukopp - honorary member of the Polish Botanical Society. In: J. B. FALIŃski, W. AdAMOWski \& B. JACKOWIAK (eds.). Synanthropization of plant cover in new Polish Research. Phytocoenosis 10 (N.S.) Suppl. Cartogr. Geobot. 9: 3-5.

PYŠEK P. 1995. On the terminology used in plant invasion studies. In: P. Pyšek, K. Prach, M. RejManek \& P. M. WADE (eds.). Plant invasions - general aspects and special problems: 71-81. The Hague (SPB Academic Publishing).

Pyšek P., Richardson D. M., Rejmanek M., Webster G. L., Williamson M. \& Kirschner J. 2004. Alien plants in checklists and floras: towards better communication between taxonomists and ecologists. Taxon 53: 131-143.

Roberts N. 2014. The Holocene. An Environmental History. 3rd ed. Oxford Wiley-Blackwell.

Schneider C., Sukopp U. \& Sukopp H. 1994. Biologischökologische Grundlagen des Schutzes gefährdeter Segetalpflanzen. Schriftenreihe für Vegetationskunde 26: 1-356.

Seitz B., Ristow M., Meissner J., Machatzi B. \& Sukopp H. 2018. Rote Liste und Gesamtartenliste der etablierten Farn- und Blütenpflanzen von Berlin. In: Der Landesbeauftragte für Naturschutz und Landschaftspflege/Senatverwaltung für Umwelt, Klima und Verkehr(Hrsg.): Rote Listen der gefährdeten Pflanzen, Pilze und Tiere von Berlin, $118 \mathrm{~S}$.

Steffen W., Crutzen P. J. \& McNeill R. 2007. The Anthropocene: Are Humans Now Overwhelming the Great 
Forces of Nature, AMBIO: A Journal of the Human Environment 36(8): 614-621.

Sukopp H. 1955. Salzstellen und Salzpflanzen. Pflanzenwelt Brandenburgs, pp. 117-131.

Sukopp H. 1957. Verzeichnis von Neufunden höherer Pflanzen aus der Mark Brandenburg und angrenzenden Gebieten. Verh. Bot. Vereins Prov. Brandenburg 83-97: 31-40.

Sukopp H. 1959/60. Vergleichende Untersuchungen der Vegetation Berliner Moore unter besonderer Berücksichtigung der anthropogenen Veränderungen. Bot. Jahrb. 79: 36-191

Sukopp H. 1962. Neophyten in natürlichen Pflanzengesellschaften Mitteleuropas. Ber. Deutsch. Bot. Ges. 75: 193-205.

SuKopp H. 1966a. Neophyten in natürlichen Pflanzengesellschaften Mitteleuropas. In: R. TÜXEN (ed.), Anthropogene Vegetation. Bericht über das international Symposium in Stolzenau/Weser 1961 der Internationalen Vereinigung für Vegetationskunde pp. 275-284. Springer Science+Business Media Dordrech.

Sukopp H. 1966b. Verluste der Berliner Flora während der letzten hundert Jahre. Sitzungsberichte der Gesellschaft Naturforschender Freunde Berlin (NF) 6: 126-136.

SuKopp H. 1967. Florenwandel und Vegetationsveränderungen in Mitteleuropa während der letzten Jahrhunderte. In: R. TüXEN et al. (eds.). Gesellschaftsentwicklung (Syndynamik). Berichte der Internationalen Symposien der Internationalen Vereinigung für Vegetationskunde 11: 469-489.

Sukopp H. 1968a. Der Einfluss des Menschen auf die Vegetation und zur Terminologie anthropogener Vegetationstypen. In: Tüxen R. (ed.) Pflanzensoziologie und Landschaftsökologie. Berichte der Internationalen Symposien der Internationalen Vereinigung für Vegetationskunde, IVV 1963, pp. 65-73.

Sukopp H. 1968b. Das Naturschutzgebiet Pfaueninsel in Berlin-Wannsee. I. Beiträge zur Landschafts und Florengeschichte. Sitzungsber. Ges. Naturforsch. Freunde Berlin N.F. 8: 93-129.

Sukopp H. 1968c. Zur Verbreitung der Laubholzmistel in Berlin. Berliner Naturschutzblätter 12(36): 280287.

Sukopp H. 1969. Der Einfluß des Menschen auf die Vegetation. Vegetatio 17: 360-371.

Sukopp H. 1970. Sagittaria latifolia Willd. - ein Agriophyt der Berliner Havelgewasser. Sonderheft Mai 1970 z. Deutsch. Naturschutztag. Berlin, Deutschen Naturschutzblatter 1-4.

Sukopp H. 1971. Beiträge zur Ökologie von Chenopodium botrys L. 1. Verbreitung und Vergesellschaftung. Verh. Bot. Verein. Provinz Brandenburg 108: 3-25.

Sukopp H. 1971. Effects of man, especially recreational activities, on littoral macrophytes. Hydrobiologia 12:331-340.

Sukopp H. 1971. Über den Rückgang von Farn- und Blütenflanzen. Belastete Landschaft - Gefährdete Umwelt, pp. 165-176.

Sukopp H. 1972. Wandel von Flora und Vegetation in Mitteleuropa unter dem Einfluß des Menschen. Berichte über Landwirtschaft. 50: 112-139.
Sukopp H. 1974. "Rote Liste" der in der Bundersrepublik Deutschland gefährderten Farn- und Blütenpflanzen (1. Fassung). Nat. Landschaft 49 (12): 315-322.

Sukopp H. 1976. Dynamik und Konstanz in der Flora der Bundesrepublik Deutschland. Schriftenreihe Vegetationskunde 10: 9-27.

Sukopp H. 1979. Florenwandel und Vegetationsveränderungen in Mitteleuropa während der letzten Jahrhunderte. In: R. TÜXEN \& W. H. SOMMER (eds) Gesellschaftsentwicklung (Syndynamik). Berichte der Internationalen Symposien der Internationalen Vereinigung für Vegetationskunde 11: 469-489.

Sukopp H. 1980. Zur Geschichte der Ausbringung von Pflanzen in den letzten hundert Jahren. Ausbringung Von Wildpflanzen. Akademie für Naturschutz und Landschaftspflege, Laufen, Tagungsberichte 5: 5-9.

SuKopP H. 1981. Veränderungen von Flora und Vegetation in Agrarlandschaften. Berichte über Landwirtschaft 197: 255-264.

Sukopp H. 1993. Ökologie und Vergesellschaftung von Veronica sublobata $\mathrm{M}$. Fischer. Berichte des Institutes fur Landschafts- und Pflanzenökologie der Universität Hohenheim 2: 255-268.

Sukopp H. 1995. Neophytie und Neophytismus. Gebietsfremde Pflanzenarten, pp. 3-32.

SuKopp H. 1998a. On the study of anthropogenic plant migrations in central Europe. Plant Invasions: Ecological Mechanisms and Human Responses, pp. 43-56.

SukopP H. 1998b. Urban ecology - scientific and practical aspects. Materiały konferencji i obrad 51 Zjazdu PTB - Gdańsk 1998, p. 465.

Sukopp H. 2001a. Neophyten. Bauhinia 15: 19-37.

Sukopp H. 2001b. Entwicklung der Kulturlandschaften Mitteleuropas und ökologische Risikobewertung des Anbaus transgener Kulturpflanzen. In: M. LEMKE \& G. WINTER (eds.). Bewertung von Umweltwirkungen von gentechnisch veränderten Organismen im Zusammenhang mit naturschutzbezogenen Fragestellungen, Schmidt, Berlin: 195-223 (UBA-Berichte 3/01).

Sukopp H. 2004. Human-caused impact on preserved vegetation. Landscape and Urban Planning 68 (4): 347-355.

Sukopp H. 2006. Apophytes in the flora of Central Europe. Polish Botanical Studies 22: 473-485.

Sukopp H. 2007. Dynamik und Konstanz in der Kulturlandschaftentwicklung. Akad. Wiss. Ber. Abh. 13: 13-34.

Sukopp H. 2008. Apophyten in der Flora von Mitteleuropa. Braunschweiger Geobot. Arb. 9: 443-458.

Sukopp H. \& Böcker R. \& Brande A. 2015. Die Kaukasische Flügelnuss in und um Berlin. Verh. Bot. Ver. Berlin Brandenburg 148: 31-81.

Sukopp H. \& Elvers H. 1982. Rote Liste der gefährdeten Pflanzen und Tiere in Berlin (West). Landschaftsentwicklung Umweltforschung 11: 1-374.

SuKopp H. \& Kowarik I. 1986. Berücksichtigung von Neophyten in Roten Listen gefährdeter Arten. Schriftenreihe für Vegetationskunde 18: 105-113.

SuKopp H. \& Kowarik I. 1987. Der Hopfen (Humulus lupulus L.) als Apophyt der Flora Mitteleuropas. Natur und Landschaft 62(9): 373-377. 
Sukopp H. \& Kowarik I. 2002. Zur Ausweitung der biologischen Vielfalt in Kulturlandschaften. Natur Zwischen Wandel und Veränderung, pp. 67-86.

Sukopp H. \& Kowarik I. 2008. Stinsenpflanzen und deren agriophytische Vorkommen. Ber. Institut LandschaftsPflanzenökologie Univ. Hohenheim 17: 81-90.

Sukopp H. \& LAnger A. 1996. Campanula rapunculoides - ein Apophyt in der Vegetation Mitteleuropas L. Verhandlungen - Gesellschaft für Ökologie 25: 261-276.

Sukopp H., Lohmeyer W., Müller T. \& Pritzer E. 1972. Die in der Bundesrepublik Deutschland gefährdeten Arten von Farn- und Blütenpflanzen. Göttinger Floristische Rundbriefe 6(4): 91-96.

Sukopp H. \& MARKstein B. 1981. Veränderung von Röhrichtstanden und Pflanzen als Indikatoren von Gewassernutzungen dargestellt am Beispiel der Havel in Berlin. Limnologica 13: 459-471.

Sukopp H. \& Markstein B. 1989. Changes of the reed beds along the Berlin Havel, 1962-1987. Aquat Bot 35(1): 27-39.

Sukopp H., Markstein B. \& Trepl L. 1975. Röhrichte unter intensivem Großstandteinfluß. Beitr. Naturk. Forsch. Südwestdeutschl. 34: 371-385.

Sukopp H. \& MAurer U. 2001. Ornamental plants: Future potential or risk for biodiversity in cities? Verhandlungen der Gesellschaft fur Ökologie 31: 104.

Sukopp H. \& Schick B. 1991. Zur Biologie neophytischer Reynoutria-Arten in Mitteleuropa. I. Über flora- und extra-floralnektarien. Verh. Bot. Ver. Berlin Brandenburg 124: 31-42.

Sukopp H. \& Schick B. 1993. Zur Biologie neophytischer Reynoutria-Arten in Mitteleuropa. II. Morphometrie der Sproßsysteme. Dissertationes Botanicae 196: 163-174.

Sukopp H. \& Scholz H. 1968. Poa bulbosa L., ein Archäophyt der Flora Mitteleuropas. Flora 157: 494-526.

Sukopp H. \& Scholz H. 1964. Parietaria pensylvanica Mühlenb. ex Willd. in Berlin. Ber. Deutsch. Bot. Ges. 77(10): 419-426.

Sukopp H. \& Scholz H. 1965. Neue Untersuchungen über Rumex triangulivalvis (Danser). Rechinger $\mathrm{f}$. in Deutschland. Berichte der Deutschen Botanischen Gesellschaft 78(10): 455-465.

Sukopp H. \& Scholz H. 1997. Herkunft der Unkräuter. Osnabrücker Naturwissenschaftliche Mitteilungen Band 23: 327-333.

SUKOPP H. \& STARFINGER U. 1995. Reynoutria sachalinensis in Europe and in the Far East: A comparison of the species ecology in its native and adventive distribution range. Plant Invasions - General Aspects and Special Problems, pp. 151-159.

Sukopp H. \& Sukopp U. 1988. Reynoutria japonica Houtt. in Japan und in Europa. Veröff. Geobot. Inst. ETH Stiftung Rübel Zürich 98: 354-372.

Sukopp H. \& Sukopp U. 1993. Das Modell der Einführung und Einbürgerung nicht heimischer Arten. Ein Beitrag zur Diskussion über die Freisetzung gentechnisch veränderter Kulturpflanzen. GAIA 2(5): 267-288.

Sukopp H. \& Sukopp U. 1993. Ecological long-term effects of cultigens becoming feral and of naturalization of non-native species. Experientia 49(3): 210-218.
Sukopp H. \& SuKopp U. 1995. Ökologische Modelle in der Begleitforschung zur transgener Kulturpflanzen. In: S. Albrecht \& V. Beusmann (eds.). Ökologie transgener Nutzpflanzen. Frankfurt/Main: Campus, Gentechnologie 31: 41-64.

Sukopp H. \& Sukopp U. 1997. Ökologische Begleitforschung und Dauerbeobachtung im Zusammenhang mit Freisetzung und Inverkehrbringen gentechnisch veränderter Kulturpflanzen. In: Chancen und Risiken der Gentechnik im Umweltschutz, pp. 43-51.

Sukopp H. \& Trautmann W. 1981. Causes of the decline of threatened plants in the Federal Republic of Germany. The Biological Aspects of Rare Plant Conservation, pp. 113-116.

Sukopp H., Trautmann W. \& Korneck D. 1978. Auswertung der Roten Liste gefährdeter Farn- und Blütenpflanzen der Bundesrepublik Deutschland für den Arten- und Biotopschutz. Schriftenreihe für Vegetationskunde 12: 1-138.

SuKopp H. \& TREPL L. 1987. Extinction and Naturalization of Plant Species as Related to Ecosystem Structure and Function. In: E.-D. Schulze \& H. Zwolfer (eds.). Ecological Studies 61: 245-276. Springer-Verlag Berlin Heidelberg.

Sukopp H. \& Trepl L. 1993. Zur Bedeutung der Introduktion und Naturalisation von Pflanzen und Tieren fur die Zukunft der Artenvielfalt. Rundgesprache der Kommission für Ökologie, "Dynamik von Flora und Fauna - Artenvielfalt und ihre Erhaltung" 6: 127-142.

Sukopp H., Winter K., Kreyer D., Maurer U., Schmitz S., VAter, G. \& Wirth P. 2006. Ecological range of invasive plant species in Central European pine (Pinus sylvestris L.) forests. Ann. For. Sci. 63: 189-203.

Sukopp H. \& Wurzel A. 2000. Changing climates and the effects on vegetation in central European cities. Arboricultural Journal 24(4): 257-281.

Sukopp H. \& Wurzel A. 2003. The effects of climate change on the vegetation of central European cities. Urban Habitats 1(1): 66-86.

Sukopp U. \& SuKopp H. 1994a. Ecological long-time effects of the growing wild of crop plants. WZB Papers FS II, pp. 94-304.

Sukopp U. \& Sukopp H. 1994b. Das Modell der Einführung und Einbügerung nicht einheimischer Pflanzen (sog. "Exotic Species Model") . In: W. Van Den Daele, PÜHLER A. \& H. Sukopp (eds.). Verfahren zur Technikfolgenabschätzung des Anbaus von Kulturpflanzen mit gentechnisch erzeugter Herbizidresistenz. Berlin: Wissenschaftszentrum 4: 101-118 (FS II 94-304)

Sukopp U. \& Sukopp H. 1994b. Ökologische LangzeitEffekte der Verwilderung von Kulturpflanzen. In: W. Van Den Daele, A. Pühler \& H. Sukopp (eds.). Verfahren zur Technikfolgenabschätzung des Anbaus von Kulturpflanzen mit gentechnisch erzeugter Herbizidresistenz. Berlin: Wissenschaftszentrum 4: 1-91 (FS II 94-304)

Sukopp U. \& Sukopp H. 1997. Ökologische dauerbeobachtung gentechnisch veränderter Kulturpflanzen. Berichte des Landesamtes für Umweltschutz Sachsen-Anhalt., Sonderheft 3: 53-70. 
Sukopp U. \& SuKopp H. 2004. Drüsiges Springkraut. Integration eines Neophyten in die Vegetation der Auen. In: U. Sukopp U., E. Walter E. et al. (eds.). Halb so Wild: Neophyten in unserer Flora, Freundeskreis Ökologisch-Botanischer Garten e. V. (Hrsg.). Bayreuth: 33.

Sukopp U. \& Sukopp H. 2006. Ökologische Dauerbeobachtung gentechnisch veränderter Kulturpflanzen. Berichte des Landesamts für Umweltschutz SachsenAnhalt, Sonderheft 3: 53-70.

Thellung A. 1905. Einteilung der Ruderal und Adventivflora in genetische Gruppen. In: O. NAEGELI und A. Thellung Die Flora des Kanton Zürich. I. Teil. Die Ruderal- und Adventivflora des Kanton Zürich. Vjschr. Naturforsch. Ges. Kanten Zürich, 50: 232-236.

Thellung A. 1915. Pflanzenwanderungen unter dem Einfluß des Menschen. Bot. Jb. 53(116) 37-66.
Thellung A. 1919. Zur Terminologie der Adventiv- und Ruderalfloristik. Allgem. Bot. Z., 24/25: 36-42.

Thellung A. 1925. Kulturpflanzen-Eigenschaften bei Unkräutern. Veröff. Geobot. Inst. Rübel in Zürich 3: 745-762.

Watson H. C. 1847. Cybelle Brittanica I.

Van Den Daele W., Pühler A. \& Sukopp H. 1996. Grüne Gentechnik im Widerstreit. Modell einer partizipativen Technikfolgenabschätzung zum Einsatz transgener herbizidresistenter Pflanzen, Weinheim: Weinheim: Verlag Chemie.

Van Den Daele W., Pühler A. \& Sukopp H. 1997. Transgenic herbicide-resistant crops: A participatory technology assessment. Summary report, WZB Discussion Paper 19: 1-100 (FS II 97-302), Wissenschaftszentrum Berlin für Sozialforschung (WZB), Berlin. 